Journal of

Health, Medicine and Nursing

(JHMN)

PREDICTORS OF ADHERENCE TO HIGHLY ACTIVE ANTIRETROVIRAL THERAPY (HAART) AMONG HIV

PATIENTS ATTENDING SELECTED COMPREHENSIVE CARE CENTRES (CCC) IN KERICHO COUNTY

Kipkirui Collins cheruiyot, Dr. Dennis Magu and Dr. Daniel Mokaya

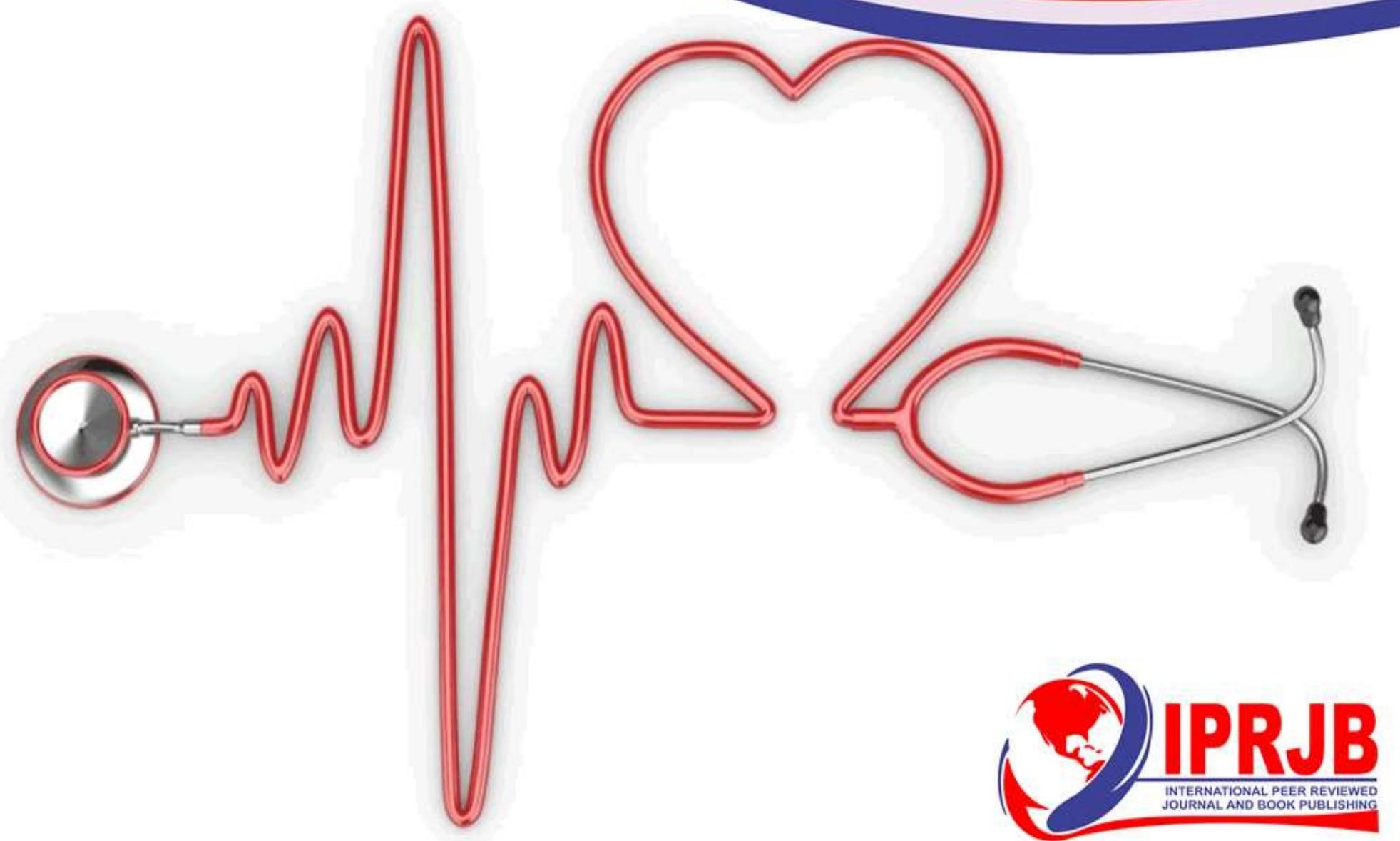


Journal of Health, Medicine and Nursing

ISSN 2520-4025 (Online)

Vol.6, Issue 1. No.1, pp 1- 13, 2021

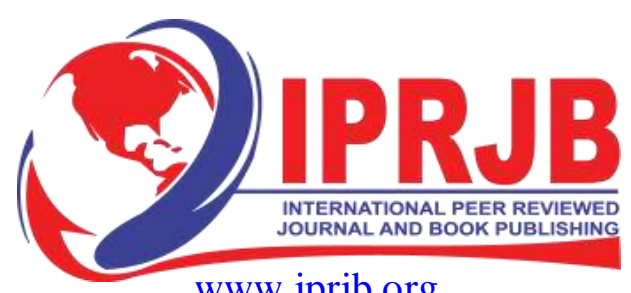

\title{
PREDICTORS OF ADHERENCE TO HIGHLY ACTIVE ANTIRETROVIRAL THERAPY (HAART) AMONG HIV PATIENTS ATTENDING SELECTED COMPREHENSIVE CARE CENTRES (CCC) IN KERICHO COUNTY
}

\author{
${ }^{1 *}$ Kipkirui Collins Cheruiyot \\ Post Graduate Student: School of Public Health: Jomo Kenyatta University of Agriculture and \\ Technology \\ Corresponding Author's E-mail: ccheruiyot09@gmail.com
}

${ }^{2}$ Dr. Dennis Magu

Lecturer: Department of Environmental health and Disease control

${ }^{3}$ Dr. Daniel Mokaya

Lecturer: Department of Environmental health and Disease control

\begin{abstract}
Purpose: The main objective of the study was to determine Predictors of adherence to Highly Active Antiretroviral Therapy among HIV patients attending selected comprehensive care centres in Kericho County. Specifically, this study sought to determine the socio-demographic and socio-economic factors that affect adherence HAART.

Methodology: A descriptive cross-sectional study was used. It involved $280 \mathrm{HIV}$ patients $(\geq 15$ years) on HAART in three selected Comprehensive Care Centres in Kericho County. Data was collected from the patients using interviewer administered semi-structured questionnaires while Key informant interviews were held with healthcare providers involved in HIV care at the selected facilities. Viral load was used as a measure of adherence. This was done by retrospective review of the patient files. The three facilities where this study was done were picked using purposive sampling. systematic sampling was then utilized to attain the calculated sample size for each facility. Data was entered into Statistical Package for Social Sciences (SPSS) version 25.0 and analysis was done through descriptive and inferential statistics. Descriptive statistics; frequencies and percentages was used to summarize the data set. Inferential statistics was done using logistic regression analysis (Univariate and multivariate). The p-value was set at 0.05.Summary statistic of independent variables was presented using frequency tables, pie charts and bar graphs.

Findings: $76 \%$ of the respondents had optimal adherence while $24 \%$ had sub-optimal adherence. More females than males were on treatment. There was an insignificant difference in adherence between males and females. Only age (category 20-24 years) $\mathrm{p}=0.023$ and expenditure on food( $\mathrm{p}=0.04)$ had significant association with adherence to HAART.

Unique contribution to theory, practice and policy: An understanding of these predictors will allow for targeted interventions to increase adherence to HAART and improve the health outcomes of PLHIV. Healthcare providers will be able to develop educational programmes and materials that target HIV patients at risk of sub-optimal adherence.
\end{abstract}

Keywords: Highly Active Antiretroviral Therapy, HIV Patients, Care Centres 
Journal of Health, Medicine and Nursing

ISSN 2520-4025 (Online)

Vol.6, Issue 1. No.1, pp 1- 13, 2021

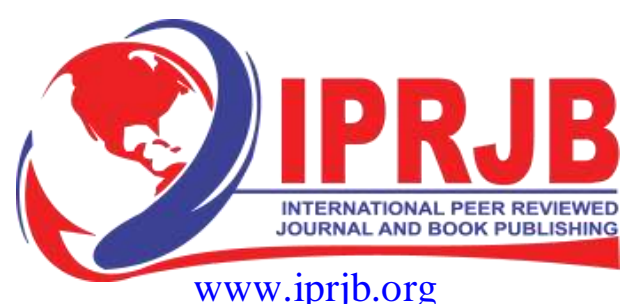

\subsection{INTRODUCTION}

Kenya has the fifth-largest number of people living with HIV (PLHIV) in the world and HIV has continued to be a leading cause of adult morbidity and mortality (NASCOP, 2020). Despite this, Kenya is widely regarded as one of sub-Saharan Africa's HIV prevention success stories. There has been a steady decline in the annual new HIV infections from the country's peak of over 200,000 in 1993, 100,000 new infections in 2013, 62,000 in 2016 and 46,000 in 2018 (UNAIDS, 2019). The decline is attributed to the scale up and the success of the Highly Active Antiretroviral Therapy (HAART) programme. HAART has been made available throughout the country in many health facilities ranging from large referral hospitals to small dispensaries.

HAART is undoubtedly the only proven remedy known to enable PLHIV to achieve and maintain utmost viral suppression, reduce the risk of drug resistance development, prevent the transmission of HIV and reduce AIDS-related mortalities. Through HAART, HIV/AIDS has been transformed into a chronic manageable disease for a substantial proportion of PLHIV who have access to treatment. Studies have shown that most people achieve viral suppression within 3-6 months of uninterrupted HAART treatment. For HAART to be effective, maximum level of adherence is required; a near perfect adherence level of $95 \%$ is required so as to achieve viral suppression. The success of the HAART programme highly depends on constant high adherence. Scaling up of HAART without addressing adherence inconsistencies further complicates the problem by limiting future treatment options.

With the UNAIDS HIV and AIDS programme setting the 95-95-95 goal to end the epidemic by the year 2030, many countries including Kenya are working towards achieving this goal. This is projected that by the year 2020, 95\% of PLHIV will know their status, $95 \%$ of the diagnosed individuals will be enrolled to uninterrupted antiretroviral therapy and out of these individuals $95 \%$ of them will have undetectable viral load. However, sub-optimal adherence to HAART has been cited as the most probable barrier towards achieving viral suppression.

Adherence to HAART is an important concept in the treatment of HIV. Its significance has been emphasized by its incorporation in the "HIV care continuum" a framework that models the dynamic stages of HIV care. The continuum is made up of five stages; Diagnosis, Linkage to care, Retention in care, Adherence to ART and Viral suppression (Kay et al., 2016). Yang et al., (2018) noted that a reduction in adherence rate to $80 \%$ results in an intense drop in the rate of viral suppression and it can drop as low as $20 \%$.

Wakibi (2010) in a study done in Kenya reported that distance to refilling clinics, time taken to refill, level of education and level of income has significant effect on adherence to HAART. Momanyi, ( 2017) reported that forgetfulness, side effects, Pill burden, depression and stigma are associated with non-adherence while socio-economic and socio-demographic factors does not significantly influence non-adherence.

According to the available literature, no factors have been consistently associated with adherence to HAART. Some factors that were reported to have statistical significance in one study were found to be statistically insignificant in other studies. This necessitates the need for contextspecific adherence studies to be undertaken. 
Journal of Health, Medicine and Nursing

ISSN 2520-4025 (Online)

Vol.6, Issue 1. No.1, pp 1- 13, 2021

\subsection{Statement of the Problem}

WWW.iprib.org

Despite HAART being made freely available in many public health facilities across the globe, adherence to treatment is still a challenge. Adherence to HAART among HIV patients remains a public health concern with sub-optimal adherence resulting in treatment failure being common. It is estimated that around $33 \%$ to $38 \%$ of PLHIV globally are non-adherent to HAART (Sandeep et al., 2013).

According to Kenya AIDS Indicator Survey (KAIS,2012) an estimated 16.3\% of PLHIV betweenc15-64 years were non-adherent to antiretroviral therapy. The African continent had an average non-adherence rate of $23 \%$ with SSA countries, including: $23 \%$ in Rwanda, $14 \%$ in Ghana and 40\% rural Zambia.Kenya is among the four countries with high HIV burden in Africa with an estimated prevalence of 4.9\% (NACC, 2018). The HIV epidemic directly or indirectly affects a big percentage of Kenya's population.

HIV patients not adhering to HAART are 3.87 times more likely to die than adherent patients on the same medication (Win et al., 2017). Sub-optimal adherence can lead to decline in Cluster of Differentiation 4 (CD4) cell counts, raising viral loads, development of drug resistance, increased risk of transmission of drug resistant strains, disease progression to AIDS and episodes of opportunistic infections.

\section{Figure 1: showing conceptual framework for the study}

\begin{tabular}{l} 
Independent variables \\
\begin{tabular}{l} 
Socio-demographic and \\
\hline socio-economic \\
characteristics
\end{tabular} \\
\hline
\end{tabular}

- Age

- Gender

- Marital status

- level of Education

- level of income

- Type of Occupation

- Nature of work schedule

Dependent variables

- Daily expenditure on food

- Type of residence

- Fare to-and-from the $\mathrm{CCC}$

\subsection{METHODOLOGY}

\subsection{Study design}

A descriptive cross-sectional study was used. It involved $280 \mathrm{HIV}$ patients ( $\geq 15$ years) on HAART in three selected Comprehensive Care Centres in Kericho County. Data was collected from the patients using interviewer administered semi-structured questionnaires while Key 
Journal of Health, Medicine and Nursing

ISSN 2520-4025 (Online)

Vol.6, Issue 1. No.1, pp 1- 13, 2021

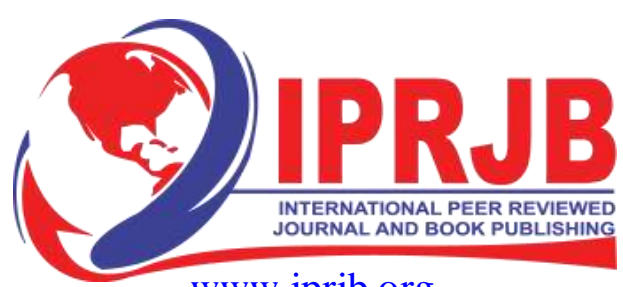

WWW.iprib.org

informant interviews were held with healthcare providers involved in HIV care at the selected facilities. Data was collected for a period of two months, July and August 2018.

Viral load was used as a measure of adherence. This was done by retrospective review of the patient file. Individuals with viral load rebound (>50 HIV-1 RNA copies/ml) from the previous viral load measure were considered to have sub-optimal adherence while those with <50 HIV-1 RNA copies/ml from the previous viral load measure were considered to have optimal adherence.

\subsection{Population, Sample size and sampling method}

The target population for this study were HIV patients ( $>15$ years) on HAART attending Kericho Referral Hospital, Londiani Sub-County Hospital and Litein mission Hospital comprehensive care centres. The three CCCs were selected purposively. This was done basing on their geographical location within Kericho county.

The required sample size was determined using Fisher's method (Fisher et al, 1991) with a 95\% confidence interval and a 5\% sampling error.

$$
\mathrm{n}=\frac{\mathrm{z}_{\frac{\alpha}{2}}^{2} \mathrm{p}(1-\mathrm{p})}{\mathrm{d}^{2}}
$$

$\mathrm{n}=$ sample size

$\mathrm{Z}=$ statistic for a level of confidence at $95 \%$ which gives a value of 1.96

$\mathrm{P}=24 \%$ which is the proportion of HIV patients on HAART not reaching optimal

Levels of adherence (Amberbir, 2008)

$\mathrm{D}=$ precision with $95 \%$ confidence interval which gives a margin of error of \pm 0.05

Therefore, the minimum sample size was,

$\mathrm{n}=\frac{1.96^{2} 0.24(1-0.24)}{0.05^{2}}=280$

The number of respondents picked from each facility were determined according to probability proportionate to size as shown in the table below.

Table 1: showing the sample size for each CCC

\begin{tabular}{lll}
\hline $\begin{array}{l}\text { Comprehensive Care } \\
\text { Centre }\end{array}$ & $\begin{array}{l}\text { Total population of patients on } \\
\text { HAART }(\geq \mathbf{1 5} \text { years })\end{array}$ & $\begin{array}{l}\text { Proportionate } \\
\text { number in sample } \\
\text { size }\end{array}$ \\
\hline $\begin{array}{l}\text { Kericho Referral Hospital } \\
\text { Londiani Sub-County hospital } \\
\text { Litein mission hospital }\end{array}$ & 5000 & $5000 / 6800 * 280=206$ \\
\hline Total & 700 & $700 / 6800 * 280=29$ \\
& 680 & $\mathbf{2 8 0}$ \\
\hline
\end{tabular}

The above table shows the CCCs where the study was conducted, the number of patient on treatment ( $\geq 15$ years) and the sample size from each facility. The figures used were facility estimates as at May 2018. 
Journal of Health, Medicine and Nursing

ISSN 2520-4025 (Online)

Vol.6, Issue 1. No.1, pp 1- 13, 2021

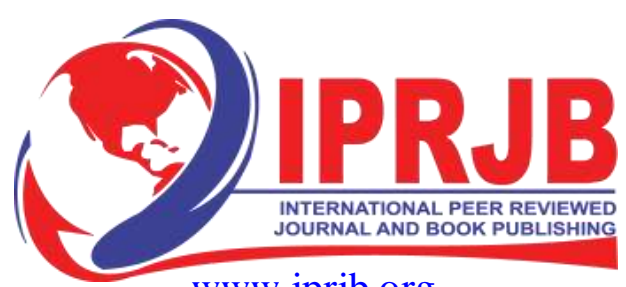

WWW.iprib.org

Systematic sampling was used to attain the sample size of 280. The data collected was coded and entered into Statistical Package for Social Sciences (SPSS) version 25 for analysis.

\subsection{Data analysis and presentation}

Data was analyzed through descriptive and inferential statistics. Descriptive statistics such as mean, frequencies, and percentages was used to summarize the data set. Logistic regression analysis was used to determine the association between adherence to HAART and various independent variables. First, Univariate logistic regression analysis was done to explore the various variables that affect adherence to HAART. $P$-value was set at 0.05 significance level and any variable whose p-value was less than 0.05 were deemed statistically significant. Variables that were deemed to be significant at 0.05 level of significance were transferred to the multivariate analysis to control possible confounders. Differences between the parameters of estimate were deemed to be statistically significant at $P<0.05$. Summary statistic of independent variables was presented using frequency tables, pie charts, percentages and graphs.

\subsection{RESULTS}

A total of 280 patients on HAART were interviewed in the three selected comprehensive care centres. However, results from only 261(94\%) patients were used during the final analysis. This is because 19 patients' files did not have results for the previous two consecutive viral load results. Since adherence was assessed using viral load results and data on viral loads was extracted retrospectively from patients' files. 19 patients did not have complete data on previous viral loads hence were excluded in the final analysis. This led to the drop in sample size from the previous calculated of 280 to 261 . The response rate was $100 \%, 280$ respondents participated fully in the interview. Majority of the respondents, $75.86 \%$ were from Kericho, $14.18 \%$ were from Litein and $9.96 \%$ from Londiani. There were more females $(62.45 \%)$ than males $(37.45 \%)$ and majority (49.43\%) of the respondents were married. The majority of the respondents; had attained secondary education $(41.76 \%)$, lived with their family $(81.23 \%)$, lived in residential places $(56.7 \%)$, casual labourers (37.93\%), earned between Ksh. 5,000-10,000 a month $(26.54 \%)$.

Table 2: Distribution of respondents according various socio-economic and sociodemographic characteristics and also adherence

\begin{tabular}{|c|c|c|c|c|}
\hline Variable & Frequency & Percent (\%) & $\begin{array}{c}\text { Optimal } \\
\text { adherence N(\%) }\end{array}$ & $\begin{array}{c}\text { Sub-optimal } \\
\text { adherence N(\%) }\end{array}$ \\
\hline \multicolumn{5}{|l|}{$\mathrm{CCC}$} \\
\hline Kericho Referral Hospital & 198 & 75.86 & $148(74.75)$ & $50(25.25)$ \\
\hline Litein Mission Hospital & 37 & 14.18 & $29(78.40)$ & $8(21.60)$ \\
\hline Londiani Sub-County Hospital & 26 & 9.96 & $21(80.77)$ & $5(19.23)$ \\
\hline \multicolumn{5}{|l|}{ Gender } \\
\hline Female & 166 & 62.45 & $111(66.89)$ & $55(33.13)$ \\
\hline Male & 95 & 37.55 & $65(68.42)$ & $30(31.58)$ \\
\hline \multicolumn{5}{|l|}{ Age } \\
\hline $15-19$ & 15 & 5.75 & $13(86.67)$ & $2(13.33)$ \\
\hline $20-24$ & 25 & 9.58 & $12(48.00)$ & $13(52.00)$ \\
\hline $25-29$ & 35 & 13.41 & $28(80.00)$ & $7(20.00)$ \\
\hline $30-34$ & 42 & 16.09 & $30(71.43)$ & $12(28.57)$ \\
\hline $35-39$ & 37 & 14.18 & $25(67.57)$ & $12(32.43)$ \\
\hline
\end{tabular}


Journal of Health, Medicine and Nursing

ISSN 2520-4025 (Online)

Vol.6, Issue 1. No.1, pp 1- 13, 2021

WWW.iprib.org

\begin{tabular}{|c|c|c|c|c|}
\hline $40-44$ & 37 & 14.18 & $28(75.68)$ & $9(24.32)$ \\
\hline $45-49$ & 31 & 11.88 & $19(61.29)$ & $12(38.71)$ \\
\hline $50+$ & 39 & 14.94 & $21(53.85)$ & $18(46.15)$ \\
\hline \multicolumn{5}{|l|}{ Marital status } \\
\hline Married & 129 & 49.43 & $87(67.44)$ & $42(32.56)$ \\
\hline Widow & 31 & 11.88 & $22(70.97)$ & $9(29.03)$ \\
\hline Widower & 3 & 1.15 & $1(33.33)$ & $2(66.67)$ \\
\hline Single & 66 & 25.29 & $45(68.18)$ & $21(31.82)$ \\
\hline Divorced & 3 & 1.15 & $3(100)$ & $0(0.00)$ \\
\hline Separated & 29 & 11.11 & $18(62.07)$ & $11(37.93)$ \\
\hline \multicolumn{5}{|l|}{ Level of Education } \\
\hline No Formal Education & 13 & 4.98 & $8(61.54)$ & $5(38.46)$ \\
\hline Primary Education & 94 & 36.02 & $58(61.70)$ & $36(38.30)$ \\
\hline Secondary Education & 109 & 41.76 & $79(72.48)$ & $30(27.52)$ \\
\hline Tertiary Education & 45 & 17.24 & $31(68.89)$ & $14(31.11)$ \\
\hline \multicolumn{5}{|c|}{ Whom do you Live with? } \\
\hline Alone & 41 & 15.70 & $30(73.17)$ & $11(26.83)$ \\
\hline Family & 212 & 81.23 & $140(66.04)$ & $72(33.96)$ \\
\hline Friends & 8 & 3.07 & $6(75.00)$ & $2(25.00)$ \\
\hline \multicolumn{5}{|l|}{ Type of residence } \\
\hline Rental & 113 & 43.3 & $82(46.59)$ & $31(36.47)$ \\
\hline Residential & 148 & 56.7 & $94(53.41)$ & $54(63.53)$ \\
\hline \multicolumn{5}{|l|}{ Type of occupation } \\
\hline Teacher & 12 & 4.60 & $8(66.67)$ & $4(33.33)$ \\
\hline Nurse & 3 & 1.15 & $3(100.0)$ & $0(0.00)$ \\
\hline Self employed & 105 & 40.23 & $62(59.00)$ & $43(41.00)$ \\
\hline Mechanic & 4 & 1.53 & $4(100.00)$ & $0(0.00)$ \\
\hline Driver & 8 & 3.07 & $6(75.00)$ & $2(25.00)$ \\
\hline Banker & 4 & 1.53 & $4(100.00)$ & $0(0.00)$ \\
\hline Casual Labourer & 99 & 37.93 & $64(84.65)$ & $25(33.35)$ \\
\hline Unemployed & 26 & 10.00 & $14(55.00)$ & $12(45.00)$ \\
\hline \multicolumn{5}{|l|}{ Type of work schedule } \\
\hline Full time & 25 & 10.55 & $18(72.00)$ & $7(28.00)$ \\
\hline Over time & 33 & 13.92 & $27(81.82)$ & $6(18.18)$ \\
\hline Part time & 80 & 33.76 & $50(62.50)$ & $30(37.50)$ \\
\hline Split shift & 3 & 1.27 & $1(33.33)$ & $2(66.67)$ \\
\hline Rotating shift & 1 & 0.42 & $1(100.00)$ & $0(0.00)$ \\
\hline Casual & 95 & 40.08 & $63(66.32)$ & $32(33.68)$ \\
\hline \multicolumn{5}{|l|}{ Level of Income } \\
\hline$<$ Kshs. 1000 & 37 & 14.18 & $24(65.79)$ & $13(34.21)$ \\
\hline Kshs. $1000-5000$ & 68 & 26.05 & $44(64.71)$ & $24(35.29)$ \\
\hline Kshs. 5001-10000 & 69 & 26.44 & $46(66.67)$ & $23(33.33)$ \\
\hline Kshs. 10001-15000 & 64 & 24.52 & $46(70.83)$ & $18(29.17)$ \\
\hline Kshs. 15001-25000 & 13 & 4.98 & $10(76.92)$ & $3(23.08)$ \\
\hline Kshs. 20001-50000 & 8 & 3.07 & $6(75.00)$ & $2(25.00)$ \\
\hline > Kshs. 50000 & 2 & 0.77 & $2(100.00)$ & $0(0.00)$ \\
\hline \multicolumn{5}{|c|}{$\begin{array}{l}\text { Fare to-and-from the } \\
\text { CCC(Ksh.) }\end{array}$} \\
\hline $0-50$ & 71 & 27.20 & $53(75.61)$ & $18(24.39)$ \\
\hline $51<100$ & 28 & 10.71 & $21(73.91)$ & $7(23.09)$ \\
\hline $101<200$ & 84 & 32.18 & $57(67.86)$ & $27(32.14)$ \\
\hline $201<400$ & 58 & 22.22 & $43(74.14)$ & $15(25.86)$ \\
\hline
\end{tabular}


Journal of Health, Medicine and Nursing

ISSN 2520-4025 (Online)

Vol.6, Issue 1. No.1, pp 1- 13, 2021

WWW.iprib.org

\begin{tabular}{|l|c|c|c|c|}
\hline$>401$ & 20 & 7.66 & $17(84.00)$ & $3(26.00)$ \\
\hline $\begin{array}{l}\text { Average daily expenditure on } \\
\text { food(Ksh.) }\end{array}$ & & & & \\
\hline $0-200$ & 220 & 89.07 & $147(66.82)$ & $73(33.18)$ \\
\hline $200-400$ & 25 & 10.12 & $18(72.00)$ & $7(28.00)$ \\
\hline $400-800$ & 2 & 0.81 & $2(100.00)$ & $0(0.00)$ \\
\hline
\end{tabular}

\subsection{Adherence levels among the respondents}

From figure below, Majority of the respondents, 198 (76\%) had optimal adherence while 63 (24\%) had sub-optimal adherence.

Figure 2: showing the adherence status among the respondents

\section{Adherence}

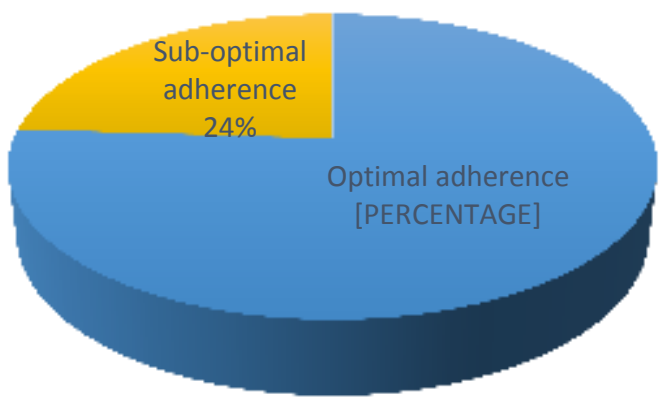

- Optimal adherence $\quad$ Sub-optimal adherence

As indicated in the table below, 42.91\%(112) of the respondents indicated that there were other issues that made it difficult for them to take their HIV medication as prescribed.

Table 3: showing other issues that made it difficult for the respondents to take their HIV medication as prescribed.

\begin{tabular}{lcc}
\hline Reason & N & \% \\
\hline Lack of food & 23 & 20.50 \\
Forgetfulness & 25 & 22.30 \\
Denial of one's HIV status & 14 & 12.50 \\
Tight work schedule & 8 & 7.10 \\
HAART side effects & 33 & 29.50 \\
Pill burden & 9 & 8.10 \\
\hline Total & $\mathbf{1 1 2}$ & $\mathbf{1 0 0 \%}$ \\
\hline
\end{tabular}

Upon analysis at the Univariate level, Age $(\mathrm{p}=0.032)$, type of residence $(\mathrm{p}=0.042)$, expenditure on food ( $\mathrm{p}=0.031)$ and fare spent to clinic $(\mathrm{p}=0.035)$ had significant association with adherence to HAART as shown in the table below. 
Journal of Health, Medicine and Nursing

ISSN 2520-4025 (Online)

Vol.6, Issue 1. No.1, pp 1- 13, 2021

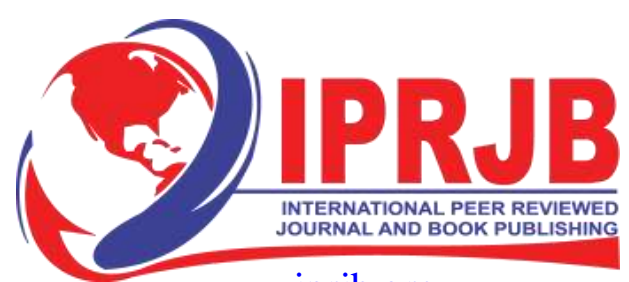

WWW.iprib.org

Table 4: Showing univariate association between socio-demographic and socio-economic characteristics and adherence to HAART

\begin{tabular}{|c|c|c|c|c|c|c|}
\hline Adherence & Odds Ratio & Std. Err. & Z & $\mathrm{P}>\mathrm{Z}$ & $\begin{array}{l}{[95 \%} \\
\text { Conf. }\end{array}$ & Interval] \\
\hline Gender & 0.994 & 0.271 & -0.020 & 0.982 & 0.582 & 1.696 \\
\hline Age & 0.9085698 & 0.058 & -1.510 & 0.032 & 0.802 & 1.029 \\
\hline Marital Status & 0.982 & 0.073 & -0.25 & 0.804 & 0.849 & 1.135 \\
\hline Level of Education & 1.227 & 0.203 & 1.240 & 0.216 & 0.888 & 1.696 \\
\hline Level of Income & 1.123 & 0.113 & 1.150 & 0.248 & 0.922 & 1.369 \\
\hline Type of occupation & 1.013 & 0.050 & 0.260 & 0.794 & 0.919 & 1.116 \\
\hline \multicolumn{7}{|l|}{ Expenditure on } \\
\hline food & 1.600 & 0.563 & 1.34 & 0.031 & 0.803 & 3.189 \\
\hline Type of residence & 0.658 & 0.179 & -1.540 & 0.042 & 0.387 & 1.120 \\
\hline Whom do live with & 1.161 & 0.247 & 0.71 & 0.079 & 0.766 & 1.764 \\
\hline $\begin{array}{l}\text { Type of work } \\
\text { schedule }\end{array}$ & 0.516 & 0.269 & -1.270 & 0.063 & 0.186 & 1.434 \\
\hline Fare spent to clinic & 0.825 & 0.084 & -1.900 & 0.035 & 0.677 & 1.006 \\
\hline
\end{tabular}

However, after adjusting for confounders at the multivariate level $(\mathrm{P}=0.05)$, only Age (20-24 years) $(\mathrm{p}=0.023)$ and expenditure on food $(\mathrm{p}=0.040)$ had significant association with adherence to HAART (Table B).

Table 5: Showing multivariate association between socio-demographic and socio-economic characteristics and adherence to HAART

\begin{tabular}{|c|c|c|c|c|c|c|}
\hline Adherence & Odds Ratio & Std. Err. & $\mathrm{Z}$ & $\mathrm{P}>\mathrm{Z}$ & $\begin{array}{l}{[95 \%} \\
\text { Conf. }\end{array}$ & Interval] \\
\hline Age & 1.141 & 0.121 & -2.27 & 0.023 & 0.260 & 0.764 \\
\hline Gender & 1.391 & 0.502 & 0.92 & 0.379 & 0.686 & 2.83 \\
\hline Marital Status & 1.862 & 0.970 & 1.19 & 0.233 & 0.671 & 1.168 \\
\hline Level of Education & 0.624 & 0.317 & -0.93 & 0.354 & 0.231 & 1.69 \\
\hline Level of Income & 0.732 & 0.489 & -0.47 & 0.640 & 0.198 & 2.708 \\
\hline Type of occupation & 0.901 & 0.820 & -0.11 & 0.908 & 0.151 & 5.365 \\
\hline Expenditure on food & 2.542 & 1.202 & 1.97 & 0.040 & 1.001 & 6.423 \\
\hline Type of residence & 0.832 & 0.578 & 0.260 & 0.719 & 0.213 & 3.250 \\
\hline Whom do you live & 0.834 & 0.519 & -0.29 & 0.770 & 0.246 & 0.282 \\
\hline Type of work schedule & 0.657 & 0.579 & -0.480 & 0.634 & 0.117 & 3.700 \\
\hline Fare spent to clinic & 1.104 & 0.402 & 0.270 & 0.517 & 0.941 & 2.252 \\
\hline
\end{tabular}

Among all the socio-economic and socio-demographic variables analyzed in this study, age and expenditure on food had significant influence on adherence. This means that respondents who were aged between 20-24 years were 1.1 times more likely to have sub-optimal adherence compared to other age groups while respondents who had no money to buy food (no food) were 2.5 times more likely to have sub-optimal adherence as compared to those respondents who had money to buy food. 
Journal of Health, Medicine and Nursing

ISSN 2520-4025 (Online)

Vol.6, Issue 1. No.1, pp 1- 13, 2021

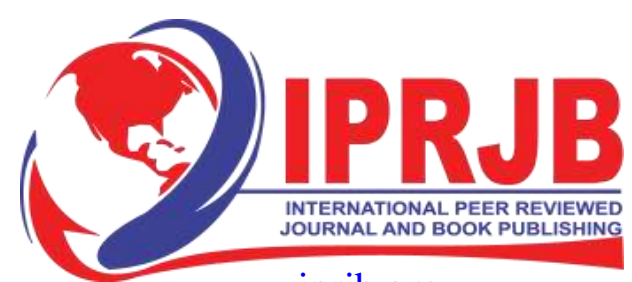

\subsection{Themes from Key Informant interviews (KII).}

WWW.iprjb.org

From July to August 2018, I conducted 16 key informant interviews with the healthcare workers involved in HIV care and treatment; Nurses, clinical officers, nutritionists, pharmacists and counselllors. The number of interviews done was determined using the saturation principle; 3 KII's in Londiani Sub-County Hospital, 5 KII's in Litein mission Hospital and 8 KII's in Kericho County Referral Hospital.

According to the healthcare providers, the following factors have significant effect on adherence to HAART;

Age-Age was mentioned repeatedly. A clinical officer from Kericho County noted "Adherence to HAART tends to increase with the patient's age, adolescents and young adults aged 30 years and below mostly struggle with adherence. From the age of 30 years and above, patients seem to understand the importance of adherence hence tend to strictly follow the medication schedule". In Litein Hospital, a counselllors noted "Older patients, above 35 years rarely give us adherence problems. However, from between 18-28 years, only a few patients manage to maintain good adherence. Most of these patients suffer from psychosocial problems ranging from denial of their HIV positive status, hopelessness, guilt about the disease and even some have reported having had suicidal thoughts".

Lack of fare to clinic- A clinical officer in charge of adherence monitoring at Kericho Referral Hospital noted "Fare to clinic has been reported by some of our patients as the reason why sometimes they don't turn up for refill. Some patients have reported having trekked for many kilometres to the clinic. We however always try to identify needy patients who for some reason cannot afford fare to clinic. we enroll them to a group "needy" and offer them financial support to enable them meet cost of fare and basic needs."

Lack of food-A nurse at the Londiani sub-county Hospital noted "some of my patients have reported not taking their medication when they have nothing to eat. They reported of side effects being worse when the drugs are taken on an empty stomach. Loss of energy, stomach pains, headaches and dizziness have been reported being common when HAART are taken on an empty stomach".

Privacy and confidentiality of one's HIV status-A clinical officer at Kericho Referral Hospital reported "when a new healthcare professional is brought into the facility, it takes us a lot of time to get used to them and eventually open up on issues affecting us". He further noted that "Some of my patients have reported to have been forced to go back without refilling because they spotted someone at the hospital who knew them and they did not want to be seen going to the clinic"

\subsection{DISCUSSSION, CONCLUSION AND RECOMMENDATION}

\section{Discussion}

This study determined the predictors of adherence to HAART among HIV positive patients attending selected comprehensive care centres in Kericho County, Kenya. Concurring with other studies, this study determined that age has a great influence on adherence. Patients in young adulthood (20-24 years) are 1.1 times more likely to have sub-optimal adherence as compared to patients in later adulthood. This is attributed to the fear being discriminated once their HIV 
Journal of Health, Medicine and Nursing

ISSN 2520-4025 (Online)

Vol.6, Issue 1. No.1, pp 1- 13, 2021

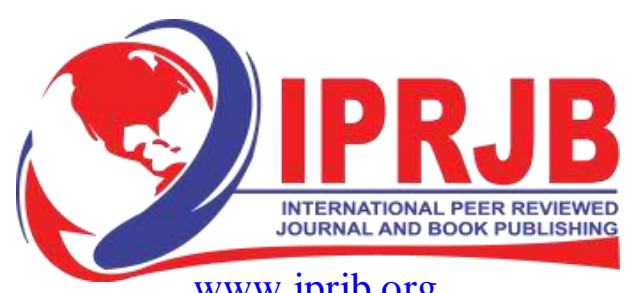

WWW.iprib.org

positive status is known by others and also the hopelessness that results from finding out their status. Such patients also reported missed clinic appointments hence eventually ran short of their medications.

The findings in this study concur with findings from another study done by wakibi (2010) in Nairobi, which reported that respondents in younger age were more than one and half times more likely not to adhere to therapy than the older adults. These findings are also consistent with the study by Fonsah et al.,(2017) who noted that there is increased risk of non-adherence to HAART among younger patients as compared to older ones. In their study, they found that patients less than 40 years were significantly less likely to be adherent as compared to those above 40 years. Sabina et al., (2006) further noted that older age is associated with higher adherence levels while younger age is a risk factor for non-adherence. MacCarthy et al.,(2018) reported that barriers to ART present additional complications to adolescents and young adults. They postulated that; poverty limited adolescents ability to buy food, school limited their privacy further disrupting ART adherence, lack of family support due to constant change in guardianship and the high pill burden is a frustration to the youth with most resorting to drug-holidays.

This study further revealed expenditure on food is also another predictor of adherence to HAART. Daily/monthly expenditure on food is an indicator of individuals' economic access to sufficient food to meet their dietary needs. The individual economic access further determines the food security status of an individual. Patients who had no money to buy food were 2.5 times more likely not to take their medication as compared to those who had money to buy food. Those had no food and opted to swallow their medication on an empty stomach reported that side effects were worse. some of the reported side effects included; stomach pains, rapid heartbeat, shivering and sweating. Such patients further reported that whenever they had no money to buy food, they didn't take their medication due to the fear of adverse effects.

These findings are in agreement with a study by Mavhandu-Mudzusi \& Fikadu (2020) who reported that food insecure individuals are 2.7times more likely to have sub-optimal adherence as compared to food secure individuals. Similar findings were also reported by Berhe et al.(2013) who noted that individuals who are unable to get enough and quality food are 2.1 times more likely to have sub-optimal adherence. Weiser et al., (2010) reported that food insecurity undermines ARVs through five mechanisms; 1) ARVs often increased appetite, and food scarcities exacerbated the resulting hunger; 2) Side effects of ARVs being much worse in the absence of food; 3) Participants were counseled on the importance of taking ARVs with a balanced diet and reported that some people did not start ARVs because they could not afford the accompanying food; 4) Competing demands between the cost of obtaining food and the cost of medical treatment and transportation for monthly clinic visits led people either to default from treatment, or to give up food and wages to get medications; and 5) Long days of farming in the fields or doing other work to earn money for food sometimes caused people to skip or forget to take their doses.

\section{Conlusion}

Majority of the respondents (76\%) were adherent to HAART. This study identified age as one of the independent predictors of adherence; young age (20-24 years) was found to be a risk factor for sub-optimal adherence while increasing age ( $\geq 30$ years) was found to promote optimal adherence. Expenditure on food was found to be predictors of adherence to HAART; having 
Journal of Health, Medicine and Nursing

ISSN 2520-4025 (Online)

Vol.6, Issue 1. No.1, pp 1- 13, 2021

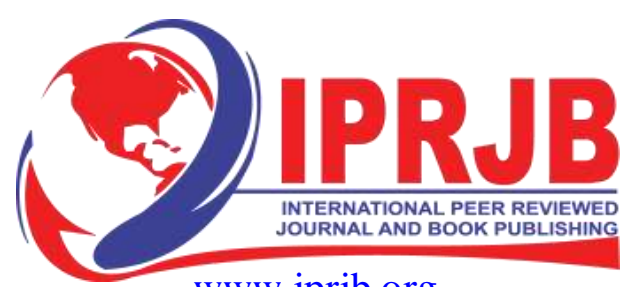

WWW.iprib.org

money to meet the competing demands which includes daily food was found to promote optimal adherence while the lack of money to meet the same needs was found to be a risk factor for suboptimal adherence.

\section{Recomndations}

Follow-up adherence monitoring should be routinely done for patients in the age category 20-24 so as to identify the challenges/ barriers to optimal adherence in this category. There should also be improvement in the mechanisms for identifying very needy cases amongst the patients so as to reduce the cases of missed clinic appointments due to lack of fare and missed doses due to lack of food.

\section{REFERENCES}

1. Amberbir, A., Woldemichael, L., Getachew, S., Girma, B., \& Deribe, K. (2008). HIV-infected persons: a prospective study in Southwest Ethiopia. Bio Med. Central journal of Public Health. , $8,265$.

2. AVERT. (2017). Global information and education on HIV and AIDS. HIV AND AIDS IN KENYA.

3. Ayalu, A. R., Sibhatu, B., Kebede, D. \& Amare, D. (2013). Determinants of Adherence to Antiretroviral Therapy among HIV-Infected Patients in Africa. ." AIDS RESEARCH AND TREATMENT . Aiids Research and Treatment.

4. Bangsberg, D. R., Perry, S. Charlebois E. D., et al. (2001). Non-adherence to highly active antiretroviral therapy predicts progression to AIDS. pubmed.gov.

5. Berhe, N., Tegabu, D. \& Alemayehu, M. (2013). Effect of nutritional factors on adherence to antiretroviral therapy among HIV-infected adults: a case control study in Northern Ethiopia. Infectitious diseases

6. Cairns, G. (2016). Very high levels of drug resistance seen in people experiencing first-line antiretroviral therapy failure in Kenya.

7. Fonsah, J.Y., Njamnshi, A.K., Kouanfack, C. (2017). Adherence to Antiretroviral Therapy (ART) in Yaounde'-Cameroon. Plos One, 11.

8. Heestermans, T., Browne, J.L., Aitken, S.C., Vervoort, S.C., KlipsteinGrobusch, K. (2016). . Determinants of adherence to antiretroviral therapy. BMJ Global health .

9. KAIS. (2012). Kenya AIDS Indicator Survey 2012. Nairobi.

10. Langebeek, N., Gisolf, E.H., Reiss, P. et al. (2014). Predictors and correlates of adherence to combination antiretroviral therapy (ART) for chronic HIV infection: a meta-analysis. BMC med.

11. Mavhandu-Mudzusi, A. H. \& Fikadu, T. N. (2020). Magnitude of non-adherence to antiretroviral therapy and associated factors among adult people living with HIV/AIDS in Benishangul-Gumuz Regional State, Ethiopi. Peer journal.

12. Momanyi, Z.K., Karanja, S. \& Mbakaya, C. (2017). Factors associated with the Prevalence of Non Adherence to Antiretroviral Therapy among HIV Positive Patients in Kibra Slums, Nairobi,Kenya. 
Journal of Health, Medicine and Nursing

ISSN 2520-4025 (Online)

Vol.6, Issue 1. No.1, pp 1- 13, 2021

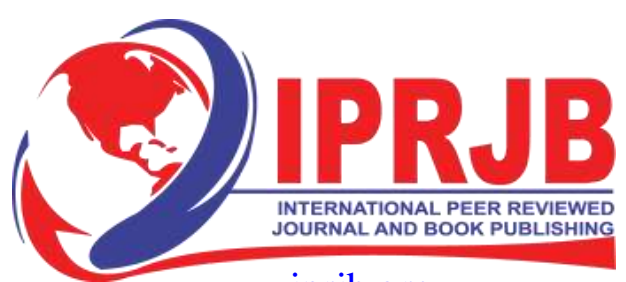

WWW.iprib.org

27. Win, L. A., Puckpinyo, A. \& Peltzer, K. (2017). Non-adherence to anti-retroviral therapy among HIV infected adults in Mon State of Myanmar.

28. Yang, Y., Luo, D., Xi, C., Huang, Z., Wang, M. \& Shuiyuan, X. (2018). Medication adherence to antiretroviral therapy among newly treated people living with HIV. 